\title{
IDEOLOGEME AS A REPRESENTATIVE OF THE BASIC CONCEPTS OF IDEOLOGY IN THE MEDIA DISCOURSE
}

\author{
Taras Lylo ${ }^{1}$
}

\begin{abstract}
The paper systematises and analyses basic definitions, classifications, functions, and forms of expression of the ideologeme as a fundamental unit of ideology, as well as reveals the specific features of functioning of ideologemes in the media discourse. In particular, it elaborates on the issue of ideologeme and mythologeme convergence, which can cause mythologization of ideology and ideologization of mythology. A special emphasis is placed on the ability of ideologemes to adapt the structural units of the myth to their content.

The purpose of the article is to determine the ability of ideologeme to represent an ideology in the media discourse in the light of its definition framework and functional parameters.
\end{abstract}

Keywords: mass media, ideologeme, mythologeme, ideology, ideologization.

\section{Introduction}

In recent years, the concept of "ideologeme" has been widely used in sociology, cultural studies, linguistics and other humanities. In the media studies it has been less popular due to the attempts to get rid of the ideological bias in mass media environment in particular, which prevents use of the term for the analysis of the media content. Such dependence is a manifestation of a broader lexicographical trend. According to the author of the study Игры в слова (Word Games) [2013] A. Vasiliev, recently linguists have often preferred to talk about the fact that the post-soviet stage lexicography "breaks free" from the earlier imposed ideological characteristics and judgements; that society has passed from the "ideologeme" system to the system of "culturemes" - i.e. language units with semantics that matches the axiological object and are devoid of axiological build-up and impregnation [Kupina, 2000, p. 183], while "de-ideologization" has become a factor that largely determines intra-cultural and inter-cultural tolerance [Kupina, Myhailova, 2002. p.25]. Other researchers [Fedotova, 2007, p. 330-334] argue that the development of information and communication technologies, global interconnection networks, and the mass media "invasion" significantly influenced the ideological space. In addition, mass information and publicist discourse along with the ideological and political ones, are basis for the representation of ideologemes. 


\section{Definitions}

The definitions of the concept of ideologeme are divided into two distinct categories: linguistic and cognitive. The researcher E. Nakhimova [Nakhimova, 2011, p. 152-156] suggests that within the framework of the linguistic vector two approaches should be outlined - the narrow (lexicological) and the wide one (semiotic). It is within the semiotic approach that the concept of ideologeme has gained a foothold. This concept was first described by M. Bakhtin. He interpreted the ideologeme as a way of representing particular ideology: "Every word/discourse betrays the ideology of its speaker; great novelistic heroes are those with the most coherent and individuated ideologies. Therefore, every speaker is an ideologue and every utterance is an ideologeme" [Bakhtin, 1981, p. 429]. Most subsequent definitions to some extent can be found in M. Bakhtin's approach. He defines the ideologeme as a way of expression or representation of a particular ideology. In western reference materials, the ideologeme is usually interpreted as a fundamental unit of ideology. M. Bakhtin views the ideologeme in a broad semiotic sense (i.e. the word as a social sign is an ideological phenomenon), however some researchers [Marling, 1994, p. 279] believe that the first semiotically driven definition of the ideologeme was provided by Julia Kristeva, who in the work Le Texte du Roman argues that the natural locus of the ideological content is a symbol. In the Renaissance, a transition from the symbol to the sign (a dominant way of thinking) occurred. J. Kristeva notes: "the novel is a narrative structure revealing the ideologeme of the sign" [Kristeva, 1986, p. 63].

Other researchers define this concept as "a word (or composed name) with the semantics containing an ideological component or a worldview paradigm wrapped in a linguistic form" [Kupina, 2000, p. 183], "a cognitive category, source of conceptual schemes and categories" [Vodak, 1997, p. 27], "mental unit that includes an ideological component" [Nakhimov, 2011, p. 194], "the minimum piece of written text or speech stream, object or symbol that is perceived by the author, listener, or reader as a reference to the meta-language or to an imaginary code of ideological norms and fundamental ideological attitudes..." [Guseinov, 2003, p. 27]. N. Klushina interprets the ideologeme as an "ideologically saturated generalising word (usually figurative), a metaphor that has a strong suggestive force (bright future, empire of evil, axis of evil, Cold War, etc.) [Klushina, 2008 , p. 38]. The researcher examines the ideologeme through the prism of communicative linguistics and argues that such words set a certain ideological modality of the text; words-ideas acquire a certain stable content, while quasi-synonymous and quasi-antonymous ranks facilitate the required stylistic and semantic rethinking of the worldview word-symbol. Other approaches define the ideologeme as "a special type of a multi-level concept within which ideologically marked conceptual features containing the collective, often stereotyped and even mythological representation of power, the state, civil society, political and ideological institutions for language speakers emerge" [Malysheva 2009, p.35].

The researcher K. Serazhym $[16,238]$ argues that ideologemes are usually constant because they are based mainly on "eternal values", the essence of which is only modified on the basis of their communicative and cultural environment. Other studies focus on the variation of the above environment, which makes it possible to treat the ideologeme as a non-self-sufficient and volatile concept (depending on the conjuncture). An example of such instability can be the dynamics of receptions of the "propaganda" ideologeme from positive in the Soviet media discourse to negative after the collapse of the USSR and its rehabilitation (primarily for the purpose of this ideologeme) in context of the Russian-Ukrainian war in the eastern Ukraine.

\section{Ideologeme and Mythologeme}

In today's media discourse, there are attempts to make the concepts of ideologeme and mythologeme synonymous or at least quasi-synonymous. This can be illustrated by 
the article Сталінградські міфологеми Путіна (Putin's Stalingrad Myths) by S. Hrabovskyi [Hrabovskyi, 2013] with the following subheading: "Never before have the ideological foundations of the Russian neo-totalitarianism been outlined so openly" and Грандіозна маніпуляція та ії витоки (Large-scale Manipulation and its Origins) [Hrabovskyi 2015] (the subheading: "The 'Great Patriotic War' without Soviet ideologemes") or the publication by O. Mandebura [Mandebura, 2005] which refers to the definition of the mythologeme of "society in clash", "revolution and division of the country into two warring camps". According to N. Shulga [Shulga, 2006], such synonymy is based on the fact that most myths are universal and are used in different versions and interpretations in forms of social relationships - such as ideology, religion, propaganda, advertising, and popular culture. However, while an ideologeme is an element of ideology, a mythologeme is defined as a structural unit of a myth; therefore, they differ significantly in a number of aspects. In particular, researchers S. Kordonskyi and N. Shulga note that firstly, ideologemes are partial and do not provide a comprehensive description of the order, rather they are concentrated ideas (sometimes to the level of slogans) of what a certain political power is dissatisfied with and how it will act in order to advance to the ideal social order. The mythologeme, on the other hand, is a stable state of social consciousness holding the canons for describing the order. "Mythologemes explain the existing things and explain why they operate in a certain way. They are a conceptual substantiation of the conduct in society... Over the past five thousand years, the internal logic of mythologemes has remained virtually the same" [Kordonskyi, 2006, p. 181]. Secondly, the ideologeme as a basis for political activity is more rational; unlike mythologemes, ideologemes are usually used consciously. Despite these differences, some researchers (N. Klushina et al.) admit the convergence of such concepts as ideologemes and mythologemes. One of the first to note this was R. Barth, who in his work Mythologies [Barth, 1996] treats the mythologeme as to some extent the essence of ideology, as a guarantor of ideological life. A favourable environment for such convergence is generated in totalitarian societies, where mythologization of ideological formations is a common thing, "as any ideology focuses on the popularisation of an artificially created world view one has to believe in, rather than on a real reflection of reality. Ideology contributes to the mythologization of the social consciousness" [Vepreva, Shadrina, 2006] and creation of political myth that develop into an ideologeme and make possible the necessary interpretation of reality. On the other hand, ideologization of society is based on the mythological ideas of reality; it makes use of these ideas for implanting in the human mind ideologemes necessary for the government.

This relationship can be illustrated by analysing the basic ideologemes that have determined the ideological framework of life in Chinese society over the past decades. In the above regulation, the symbolism of numbers is essential - it was used by ancient philosophical schools attempting to understand and explain the rhythms of cosmic life and create their parallels in the earthly life. It is well known that everything can be reduced to two principles (female yin and male yang), the five elements (water, fire, wood, metal, earth) or eight trigrams. Not only did the use of numerological terms explain the order of things, but it also facilitated memorisation of concepts, rules and theories. Communist ideologues realised that state governance would be more effective if political terminology and basic ideologemes for society were encoded in catchy slogans. This is how the ideological encoding of party directives, role models and phenomena to be condemned was implemented. As a result, appeared such ideologemes as "the third world", "one country, two systems" (referring to the reintegration of Hong Kong with China in 1997), "one central task and two basic points" (this ideologeme expresses the essence of the today's obligatory policy of building socialism with Chinese specifics), "two alls" (all that Mao did was correct and all he said to do was appropriate; after Deng Xiaoping came to power, this ideologeme was replaced with "the sole criterion of knowing the truth is practice"), "four modernisations" (actualised by Deng Xiaoping, it involves modernisation as a condition for building socialism, industry, agriculture, science and culture), "the four 
cardinal principles" (recorded in the preamble to the constitution and the statute of the Communist party: the socialist path, dictatorship of the proletariat, leadership of the party and the Marxist-Leninist-Maoist ideology; in 1982 "the dictatorship of the proletariat" was replaced with "people's democratic dictatorship", and in 1997, the four ideological principles were supplemented with the fifth one - "ideas of Deng Xiaoping"), "five black elements" (the ideologeme appeared during the "cultural revolution" and regulated class divisions until 1983, it was used to refer to the categories of society subjected to repression: landlords, rich peasants, counter-revolutionaries, generals, representatives of rightwing views), "five red elements" (workers, poor peasants and middle peasants, revolutionary cadres of the party, soldiers of the revolution or revolution martyrs). The system of the most important print media of China was also marked with an ideologeme using numbers - "seven newspapers and one magazine": newspapers People's Daily (Renmin Ribao), People's Liberation Army Daily (Jefangjun Bao), The Light Daily (Guangming Ribao), Worker's Daily (Gongren Ribao), China Youth Daily (Zhonguo Qingnian Bao), Economic Daily (Jingji Ribao), Reference News (Cankao Xiaoxi) and the journal Seeking the Truth (Qiu Shi) - the theoretical organ of the CPC Central Committee. These examples demonstrate the possibility of both ideologization of a myth and mythologization of an ideology, as well as the ability of ideologemes to adapt myths and symbols to their content.

\section{Classification}

Researchers single out typological and aspectual classifications of ideologemes. According to N. Klushina, the publicist discourse manifests two main types of ideologemes: social (reflecting the paradigms and reference marks of society at a particular period of its development) and personal. In the context of social ideologemes, the researcher described ideologemes that are conceptual for this type of discourse - they are fundamental, ontological ideologemes for any society but have particular ethno-specific content. The term basic ideologemes is used by such researchers as T. Kuteneva [Kuteneva, 2013], I. Vepreva and T. Shadrina, who argue that basic ideologemes contain features that are ideologically important in a certain period creating the ideological detonatum. For example, model of the future, image of the state, national idea, dictatorship of the proletariat, nationalism, socialism, conservatism, etc. Personal ideologemes tend to emerge around heads of states, leaders or heroes (the father of peoples (Stalin), the chief designer (Khrushchev), the true Leninist (Brezhnev), the architect of perestroika (Gorbachev), Tsar Boris (Yeltsin), etc.). It should be noted that this classification is not quite correct, since any ideologeme (including personal one) is socially important, because a dictionary defines the word social as associated with social life and relationships of people in society. Other researchers [Chudinov, 2003] suggest distinguishing between two types of ideologemes in political communication. The first consists of words which meaning varies for supporters of different political views (democracy, capitalism, socialism...). The second includes terms used exclusively by supporters of certain political views (socialist commonwealth countries/Soviet satellites). The Russian scholar E. Malysheva [Malysheva, 2009, p. 38] comes up with a rather profound classification of ideologemes:

- based on the nature of conceptualisation of information: concept-ideologemes (nation, flag), frame-ideologemes (Olympics, sports), gestalt-ideologemes (freedom, equality), archetype-ideologemes (Lenin, Stalin, Putin);

- based on the area of use and understanding by language speakers: commonly used ideologemes that are understood differently (people, freedom), commonly used ideologemes that are understood in the same way (sports, homeland), ideologemes of limited use (the researcher illustrates this category with a controversial ideologeme "Soviet soldiers - liberators" - comment added by T. L.);

- taking into account the pragmatic component: ideologemes with the positive axiological modus (homeland, flag), ideologemes with the negative axiological modus (terror, 
fascism), ideologemes with the mixed axiological modus (president, patriotism, democracy);

- based on relevance/irrelevance in the current ideological image of the world: ideologemes-historicisms (the Soviet people, socialist competition); new ideologemes or contemporary ideologemes (coercion to peace, tolerance) re-actualized ideologemes (Governor, Duma); universal ideologemes that are always topical (homeland, patriotism, anthem).

According to other classifications [Karamova, 2015], ideologemes are divided into mono-ideological ideologemes - phraseologemes loaded with ideological meaning relevant to a particular ideology; and poly-ideological ideologemes that are relevant for more than one ideology.

\section{Functions}

One of the basic functions of ideologemes, that stems from the definitions of the term, is the function of the language presentation of ideology or ideological concepts and, consequently, ideologization of public consciousness through "explication and representation of this or that ideology" [Bakhtin, 1981, p. 101, p.104]. Another function of ideologemes is the axiological one. Its essence lies in the ability of ideologemes to "group around a significant ideological concept that underlies axiological categories" [Zhuravlev, 2004] and to establish a certain "axiological model" in the public mind. The moral and didactic function, according to some researchers [Klushina, 2008], is associated primarily with personal ideologemes that help to shape the patterns of social behaviour.

Ideologemes are rigid regulatory structures that do not allow anything that could undermine their stability (and consequently the stability of the social order) to enter their internal sense and value boundaries, hence it makes sense to single out the function of stabilisation and consolidation of the ideological priorities of society.

The ideologeme is also described as the key and communicative unit of social and political discourse, as a mean of ideological and political influence on socio-cultural activities of the public and as a uniting factor of society around the category of the public good - therefore we can talk of the integrative function of ideologemes.

Some authors [Piontek, 2010, p. 85] interpret the ideologeme as a part of ideology, an element of the ideological system that helps to understand and assess the attitudes of individuals or groups of individuals towards reality. This brings us to another function of ideologemes - i.e. a mediator between ideology and the attitude towards ideology.

In the media discourse, ideologemes also play the role of a substitute for historical facts that are disadvantageous from the point of view of ideological interpretations of a reality, particularly historic reality. When analysing the mechanisms of modern Russian propaganda, the editor of the right-wing liberal newspaper Visión Independiente Kitty Sanders notes that at the first stage propagandists clog the information field around the enemy with their information viruses, memes and ideologemes, then after legitimising their attack on the enemy in the eyes of the world public opinion, they try to drag and neutralise the enemy in their information and semantic space under the guise of "objective reality". As a result, instead of the memory of the tragic victims of World War II, the ideologeme of the "great victory" appears. In this context, another method often works: a certain historical fact is painted as an alien ideologeme to reduce the status and make the fact unreliable. An example of this is the publication of Nikolai Shendarev under the eloquent title Голодомор - это идеологема украинского национализма (Holodomor (The Great Famine) - an Ideologeme of Ukrainian Nationalism) [Shendarev, 2016].

\section{Forms of Expression}

According to M. Novak, ideologemes always express the basic concepts of ideol- 
ogy, thus acquiring different forms of expression. Of course, ideologemes exist in the form of a sign (word, visual image), and are expressed in semantic parameters. However, the "form of expression of ideologemes does not have to be "materially" equivalent to the content" [Novak, 2013]. For example, the ideologeme of "consumerism" can be introduced into the human mind without any material sign form. This type of relationship between the content and the form of a sign is described among others by Giulietto Chiesa, when he analyses the functioning of the ideologemes of the consumerism ideology in the advertising text. He describes a vehicle ad that reads as: "Get ready to want it!". The researcher believes that this phrase comprises the spirit and the ideology of the era, the essence of which comes down to the following imperative: "Remember, your desires do not belong to you. We offer them to you readymade. You only need to get ready for them". The author adds: "This is not advertising anymore, this is a lifestyle imposed on the population of the planet" [Chiesa, 2006, p. 234].

\section{Conclusions}

The ideologeme is a unit of ideology and its explication. It can not only form an individual's attitude to reality, but primarily it can construct this reality on the axiological level and even replace it. Ideologemes are socially conditioned, i.e. their value core directly depends on the social affiliation of those who articulate these ideologemes. A characteristic feature of the functioning of ideologemes in the modern media text is their ability to break free from the formal characteristics of their ideological existence, while preserving their content and suggestive purpose.

\section{References}

BAKHTIN M. (1981), The dialogic imagination, University of Texas Press, Texas.

BART R. (1996), Mifologii, Izd-vo im. Sabashnikovyih, Moskva.

CHUDNIOV A. (2003), Metaforicheskaya mozaika v sovremennoy politicheskoy kommunikatsii, Ural. gos. ped. un-t, Ekaterinburg.

FEDOTOVA N. (2007), Ideologema "grazhdanskoe obschestvo» kak diskurs, kommunikatsiya, dialog, [in:] Brennoe i vechnoe: sotsialno-mifologicheskie i politosofskie izmereniya ideologii v «massovyih obschestvah», NovGU im. Yaroslava Mudrogo, Velikiy Novgorod, pp. 330-334, [online: October 22, 2016], http://www.brennoe-i-vechnoe.narod.ru/07-93.html

GRABOVSKIY S. (2013), Stalinski mifologemi Putina, Den, № 20, 5 lyut.

GRABOVSKIY S. (2015), Grandwozna manшpulyatswya ta yiyi vitoki, // Den, № 106, 19-20 chervnya.

GUSEYNOV G. (2003), Sovetskie ideologemyi v russkom diskurse 1990-h, Tri kvadrata, Moskva.

KARAMOVA A. (2015), Ideologemyi: opredelenie ponyatiya i tipologiya, [in:] Sovremennyie problemyi nauki i obrazovaniya, issue No 2-1.

KIEZA D. (2006), Voyna imperiy: Vostok - Zapad. Razdel sfer vliyaniya, EKSMO, Moskva.

KLUSHINA N. (2008) Lingvistika ubezhdeniya: intentsionalnyie kategorii publitsisticheskogo teksta, [online: February 2, 2016], [in:] Mediaskop, volume No 1, http://www.mediascope.ru/?q=node/67

KLUSHINA N. (2008), Intentsionalnyie kategorii publitsisticheskogo teksta (na materiale peryodicheskih izdaniy 2000-2008 rr.), Moskva.

KORDONSKIY S. (2006), Ryinki vlasti, OGI, Moskva.

KRISTEVA J. (1986), The Kristeva Reader, Columbia University Press, New York.

KUPINA N., MIHALYOVA O. (2002), Lingvisticheskie problemyi tolerantnosti, [in:] Mir russkogo slova, issue No 5, p. 22-27.

KUPINA, N. (2000), Yazyikovoe stroitelstvo: ot sistemyi ideologem k sisteme kulturem, [in:] Russkiy yazyik segodnya, issue No 1, p. 182-189.

KUTENEVA T. (2013), Bazovyie ideologemyi sovetskoy epohi. Smyislovaya dinamika, LAMBERT Academic Publishing.

MALYISHEVA E. (2009), Ideologema kak lingvokognitivnyiy fenomen: opredelenie i klassifikatsiya, Politicheska- 
ya lingvistika, issue № 4, p. 32-40.

MANDEBURA 0. (2005), List vid podrugi, Den, № 47, 18 ber.

MARLING W. (1994), The formal ideologeme, Semiotica, 98:3/4, p. 277-299, [online: November 15, 2016], http://www.williammarling.com/dox/ideologeme.pdf

NAHIMOVA E. (2011), Ideologema "Stalin" v sovremennoy massovoy kommunikatsii [in:] Politicheskaya lingvistika, issue No 2 (36), p. 152-156.

NAHIMOVA E. (2011), Pretsedentnyie onimyi v sovremennoy rossiyskoy massovoy kommunikatsii: teoriya i metodika kognitivno-diskursivnogo issledovaniya, GOU VPO "Ural. gos.ped. un-t", Ekaterinburg.

NOVAK M. (2013), Kulturno-semioticheskiy analiz ideologem obschestva potrebleniya, [in:] Sovremennyiy diskurs-analiz, issue No 7, p. 53-50.

PIONTEK B. (2010) Ideologema kak klyuchevaya leksicheskaya edinitsa obschestvenno-politicheskogo diskursa i kak kontsept obschestvennogo soznaniya sovremennoy yazyikovoy lichnosti v Rossii i v Polshe, [in:] Vestnik Moskovskogo universiteta, Ser. 19, Lingvistika i mezhkulturnaya kommunikatsiya, No 1, p. 85-95.

SERAZHIM K. (2003), Diskurs yak sotsiolingvistichniy fenomen suchasnogo komunikativnogo prostoru (metodologichniy, pragmatiko-semantichniy i zhanrovo-lingvistichniy aspekti: na materiali politichnogo riznovidu ukrayinskogo masovoinformatsiynogo diskursu), Kyiv.

SHENDAREV N. (2016). Byishok: Golodomor - eto ideologema ukrainskogo natsionalizma, [online: June 2, 2016], [in:] Nation News, 2 iyunya, http://nation-news.ru/195975-byshok-golodomor-eto-ideologema-ukrainskogo-nacionalizma

SHULGA H. (2006), Mifologema v strukture massovogo politicheskogo soznaniya, Omsk, [online: December 12, 2016], http://cheloveknauka.com/mifologema-v-strukture-massovogo-politicheskogo-soznaniya\#ixzz4GdJOGmIF

VASILIEV, A. (2013), Igryi v slova. Manipulyativnyie operatsii v tekstah SMI, Sankt-Peterburg, Zlatoust.

VEPREVA I., SHADRINA T. (2006) Ideologema i mifologema: interpretatsiya terminov [in:] Nauchnyie trudyi professorov Uralskogo in-ta ekonomiki, upravleniya i prava, issue No 3, p. 120-131.

VODAK R. (1997), Yazyik. Diskurs. Politika, Peremena, Volgograd.

ZHURAVLEV S. (2004), Ideologemyi i ih aktualizatsiya v russkom leksikograficheskom diskurse, Yoshkar-Ola. 